\title{
Tsafon
}

Revue d'études juives du Nord

$78 \mid 2019$

L'antijudaïsme dans l'Antiquité

\section{Joly Laurent, L'État contre les juifs - Vichy, les nazis et la persécution antisémite}

\section{Monique Heddebaut}

\section{(2) OpenEdition}

1 Journals

Édition électronique

URL : https://journals.openedition.org/tsafon/2688

DOI : $10.4000 /$ tsafon. 2688

ISSN : 2609-6420

Éditeur

Association Jean-Marie Delmaire

\section{Édition imprimée}

Date de publication : 1 décembre 2019

Pagination : 188

ISSN : 1149-6630

\section{Référence électronique}

Monique Heddebaut, « Joly Laurent, L'État contre les juifs - Vichy, les nazis et la persécution

antisémite », Tsafon [En ligne], 78 | 2019, mis en ligne le 01 décembre 2019, consulté le 25 juin 2021.

URL : http://journals.openedition.org/tsafon/2688 ; DOI : https://doi.org/10.4000/tsafon.2688

Ce document a été généré automatiquement le 25 juin 2021.

Tsafon. Revues d'études juives du Nord 


\title{
Joly Laurent, L'État contre les juifs - Vichy, les nazis et la persécution antisémite
}

\author{
Monique Heddebaut
}

\section{RÉFÉRENCE}

Paris, Grasset, 368 p., 20,90€

1 Directeur de recherche au CNRS (CRH-EHESS), Laurent Joly est l'auteur de plusieurs livres sur l'antisémitisme et la Shoah en France, dont Vichy dans la « solution finale " (2006) et L'antisémitisme de bureau (2011), d'une biographie de Xavier Vallat (2001) et de Dénoncer les Juifs sous l'Occupation (2017).

Dans un nouvel ouvrage - L'État contre les Juifs - l'historien répond à des questions essentielles pour qui s'interroge sur les fondements de la politique de collaboration du maréchal Pétain. Pourquoi, dès l'été 1940 , ce régime a-t-il impulsé une politique antisémite ? Quelle était la proximité entre les lois de Nuremberg de 1935 et le statut des juifs du 3 octobre 1940 ? Pourquoi le chef de l'État a-t-il accepté de contribuer aux déportations massives décidées par les nazis en 1942 et surtout d'assumer pleinement ces opérations, à Paris comme en zone « libre »? Dans quelle mesure l'administration a-t-elle collaboré à la politique génocidaire ? Était-ce pour protéger les juifs français quitte à « sacrifier » les étrangers ? Si Vichy a continué de seconder la politique nazie après l'été 1943, que savaient Laval, Bousquet, les dirigeants du Commissariat Général aux Questions Juives, de la politique d'extermination ? Et enfin, l'épuration a-t-elle ignoré le sort des juifs?

3 Laurent Joly s'est appuyé sur de nombreuses sources inédites, a cherché à restituer les marges de manœuvre des agents et les effets concrets de leurs décisions. Il s'est attaché à retracer l'histoire des persécutions dans une approche institutionnelle, au plus près 
des exécuteurs, des victimes et des témoins. Cette remarquable synthèse se situe dans la lignée des travaux de Robert Paxton et Serge Klarsfeld.

4 Un regret toutefois : si Laurent Joly a mis en perspective la « répartition législative et institutionnelle de la politique antijuive entre les deux zones » entre 1940 et 1942, force est de constater que les départements du Nord et du Pas-de-Calais sous la tutelle militaire de Bruxelles échappent à son champ de recherche, de même la zone d'occupation italienne. 